\title{
Variation in Content and Distribution of Magnesium, and its Influence on Survival, in Aerobacter aerogenes Grown in a Chemostat
}

\author{
By D. W. TEMPEST AND R. E. STRANGE \\ Microbiological Research Establishment, Porton Down, Wiltshire
}

(Received 6 January 1966)

\begin{abstract}
SUMMARY
The magnesium and RNA contents of Aerobacter aerogenes, growthlimited by $\mathrm{Mg}^{2+}, \mathrm{K}^{+}, \mathrm{NH}_{4}{ }^{+}$or carbon source, in defined media at $\mathbf{3 5}^{\circ}$ increased with growth rate. The results support the view that the amounts of these constituents are functions of the growth rate and are interdependent. Up to $26 \%$ of the total $\mathrm{Mg}^{2+}$ of bacteria freshly harvested from cultures containing excess magnesium was loosely bound to the bacterial surface; this adsorbed $\mathrm{Mg}^{2+}$ was removed by washing with $0 \cdot 85 \%(\mathrm{w} / \mathrm{v})$ $\mathrm{NaCl}$ but was unaffected by distilled water. $\mathrm{Mg}^{2+}-$ limited bacteria had no surface-adsorbed magnesium. Surface-adsorbed $\mathbf{M g}^{2+}$ stimulated polysaccharide synthesis, and affected the response of bacteria in saline buffer to stresses including starvation, heat-accelerated and substrate-accelerated death, and cold shock.
\end{abstract}

\section{INTRODUCTION}

When the growth rate of Aerobacter aerogenes cultures in a chemostat was limited by the supply of $\mathrm{Mg}^{2+}$, the bacterial concentration varied with dilution rate (Tempest, Hunter \& Sykes, 1965) which, assuming quantitative uptake of $\mathrm{Mg}^{2+}$ from the medium, indicated a variation in cellular $\mathrm{Mg}^{2+}$ content with growth rate. This assumption has now been confirmed by direct determination of the distribution of $\mathrm{Mg}^{2+}$ in $\mathrm{Mg}^{2+-}$ limited cultures by the Titan Yellow method of Gardner (1946) which, when used as described below, gave accurate and reliable results. Furthermore, it was found that the $\mathrm{Mg}^{2+}$ content of bacteria growth-limited by substances other than $\mathbf{M g}^{2+}$, increased with the growth rate. $\mathrm{The}^{\mathrm{Mg}} \mathrm{M}^{2+}$ associated with bacteria growth-limited by substances other than $\mathbf{M g}^{2+}$ included some $\mathbf{M g}^{2+}$ that was loosely bound; this 'adsorbed $\mathrm{Mg}^{2+}$ ' could be removed by washing with salt solution (Strange \& Shon, 1964). Adsorbed $\mathrm{Mg}^{2+}$ affected the response of the bacteria to subsequent stresses. The present paper records data which indicate a relationship between the intracellular $\mathrm{Mg}^{2+}$ and RNA contents of $A$. aerogenes grown under a variety of growth-limiting conditions and presents evidence which shows that surface-adsorbed magnesium is advantageous for the survival of the organisms in unfavourable conditions.

\section{METHODS}

Organism and cultural conditions. Aerobacter aerogenes ( мCTC 418) was grown in 0.5 l. Porton-type chemostats (Herbert, Phipps \& Tempest, 1965) in defined media containing growth-limiting concentrations of $\mathrm{Mg}^{2+}$, glycerol (Tempest et al. 1965) 
or $\mathrm{K}^{+}$. The $\mathrm{K}^{+}$-limited medium contained: $\mathrm{Na}_{2} \mathrm{HPO}_{4}, 5 \cdot 0 \times 10^{-3} \mathrm{M} ;\left(\mathrm{NH}_{4}\right) \mathrm{H}_{2} \mathrm{PO}_{4}$, $4.5 \times 10^{-2} \mathrm{M} ;\left(\mathrm{NH}_{4}\right){ }_{2} \mathrm{SO}_{4}, 2.5 \times 10^{-2} \mathrm{M}$; citric acid, $1.0 \times 10^{-3} \mathrm{M} ; \mathrm{MgCl}_{2} 1.25 \times 10^{-3} \mathrm{M}$; $\mathrm{CaCl}_{2}$ and $\mathrm{FeCl}_{3}$, each $1.0 \times 10^{-4} \mathrm{M}$; trace amounts of $\mathrm{Mn}^{2+}, \mathrm{Cu}^{2+}$ and $\mathrm{NaMoO}_{4}$. Glycerol was added to a final concentration of $30 \mathrm{mg}$./ml., and $\mathrm{K}_{2} \mathrm{SO}_{4}$ to $5 \cdot 0 \times 10^{-4} \mathrm{M}$. In addition, ammonium-limited and carbon-limited cultures of $A$. aerogenes were grown in defined media in a smaller chemostat (designed by Dr D. Herbert) as described by Postgate \& Hunter (1962), but with a culture volume of $0.25 \mathrm{l}$. In each case, the dilution rate was progressively increased from 0.1 to $0.8 \mathrm{vol} / \mathrm{hr}$ and samples were taken (see below) at several intermediate 'steady state' growth-rate values. Exponential phase $\boldsymbol{A}$. aerogenes organisms were harvested from shaken batch cultures of the organisms in a defined medium containing mannitol (Strange \& Dark, 1962).

Survival studies. Washed suspensions of bacteria were subjected to heat stress at $48^{\circ}$ as described by Strange \& Shon (1964), to carbon substrate accelerated death (Postgate \& Hunter, 1963; 1964) as described by Strange \& Dark (1965), and to chilling at $0^{\circ}$ as described by Strange \& Dark (1962). Viabilities were determined with the slide culture method of Postgate, Crumpton \& Hunter (1961), with an enriched agar medium similar to theirs except that glucose $(0 \cdot 2 \%, \mathrm{w} / \mathrm{v})$ replaced glycerol. Saline phosphate contained $0 \cdot 108 \mathrm{M}-\mathrm{NaCl}$ and $0.02 \mathrm{M}-$ potassium phosphate buffer ( $\mathrm{pH} 6 \cdot 5)$.

Analytical methods. Magnesium in bacteria and culture filtrates was determined by the Titan Yellow colorimetric method (Gardner, 1946). $\mathrm{Mg}^{2+}$ was extracted from bacteria as follows. Duplicate samples of culture $(10 \mathrm{ml}$. containing equiv. 1-10 mg. dry wt bacteria/ml.) were centrifuged at $3000 \mathrm{~g}$ for $10 \mathrm{~min}$.; the packed cell pellets were suspended in a suitable diluent (see Results) and re-sedimented by centrifugation. The washed pellets were resuspended in ice-cold water $(2.5 \mathrm{ml}$.) and cold $2 \mathrm{~N}-\mathrm{HClO}_{4}\left(2 \cdot 5 \mathrm{ml}\right.$.) added; after standing at $4^{\circ}$ for $15 \mathrm{~min}$., the suspensions were centrifuged and the clear extracts decanted into $10 \mathrm{ml}$. graduated test tubes. The pellets were re-extracted with cold $\mathrm{N}-\mathrm{HClO}_{4}(4 \mathrm{ml}$.) as before and the combined extracts diluted to $10 \mathrm{ml}$. with $\mathrm{N}-\mathrm{HClO}_{4}$. Total removal of $\mathrm{Mg}^{2+}$ from the organisms was confirmed by wet ashing the pellets followed by acid extraction and analysis for $\mathrm{Mg}^{2+}$. The $\mathrm{Mg}^{2+}$-content of $\mathrm{HClO}_{4}$-extracts and culture filtrates was determined as follows. Reaction mixtures containing (final vol., $2.5 \mathrm{ml}$.) $1 \mathrm{~m}$-mole $\mathrm{HClO}_{4}, \mathbf{0 . 4} \mathrm{mg}$. gum ghatti, $\mathbf{0} \cdot 15 \mathrm{mg}$. Titan Yellow and 2-12 $\mu \mathrm{g}$. $\mathrm{Mg}^{2+}$ were prepared; colour was developed by adding $1 \mathrm{ml} .3 \mathrm{~N}-\mathrm{NaOH}$ and measured after exactly 5 min. with a Bausch \& Lomb 'Spectronic 20' spectrophotometer at $540 \mathrm{~m} \mu$. The amount of $\mathrm{HClO}_{4}$ present in the reaction mixtures was important because colour formation decreased as its concentration increased. Under the conditions given, colour formed was directly proportional to $\mathrm{Mg}^{2+}$ concentrations between 2 and $12 \mu \mathrm{g}$. The presence of interfering substances in acid extracts was assessed by recovery of standard amounts of added $\mathrm{Mg}^{2+}$ from extracts. The only substance found seriously to interefere in the assay and which was present in significant concentration in some extracts was Polyglycol P-2000, a polypropylene glycol added to cultures to suppress foaming. This substance was quantitatively removed from extracts by two extractions with an equal volume of 'Analar' grade light petroleum (60-80 fraction). Bacterial dry weights, carbohydrate and RNA-contents were determined as previously described (Tempest et al. 1965). 


\section{RESULTS \\ $\mathrm{Mg}^{2+}$-content of Aerobacter aerogenes as a function of growth rate and limiting substrate}

Previous work (Strange \& Shon, 1964) showed that Aerobacter aerogenes adsorbed $\mathrm{Mg}^{2+}$ from solutions of magnesium salts but this adsorption progressively decreased in the presence of increasing concentrations of $\mathrm{Na}^{+}$or $\mathrm{K}^{+}$. It therefore seemed likely that bacteria separated from cultures containing excess $\mathrm{Mg}^{2+}$ would contain some $\mathrm{Mg}^{2+}$ adsorbed to their surface. This possibility was examined by washing samples of bacteria sedimented from cultures, with distilled water and parallel samples with $\mathbf{0 . 8 5} \%(\mathrm{w} / \mathrm{v}) \mathrm{NaCl}$, before acid extraction for $\mathrm{Mg}^{2+}$ assay. The results (Table $\mathrm{I}$ ) show that, with the exception of $\mathrm{Mg}^{2+}$-limited organisms, the $\mathrm{Mg}^{2+}$ contents of water-washed bacteria were significantly higher than those of saline-washed bacteria.

Table 1. Magnesium content of $\mathbf{M g}^{2+-}$, glycerol-, $\mathrm{K}^{+-}$and $\mathrm{NH}_{4}{ }^{+-l i m i t e d}$ Aerobacter aerogenes grown at various dilution rates, and the effect of the washing procedure on adsorbed magnesium

Samples of bacteria, separated from chemostat cultures, were washed with distilled water or $0.85 \%(w / v) ~ \mathrm{NaCl}$ and extracted with $\mathrm{N}-\mathrm{HClO}_{4}$ for $\mathrm{Mg}^{2+}$ assay (see Methods). For each growth limitation, figures in column $(a)$ refer to $\mathrm{Mg}^{2+}$ content of water-washed bacteria, and in column $(b)$ to $\mathrm{Mg}^{2+}$ content of saline-washed bacteria. All values are expressed as $\mathrm{g}$. $\mathrm{Mg}^{2+} / 100 \mathrm{~g}$. dried organisms.

\begin{tabular}{|c|c|c|c|c|c|c|c|c|c|c|c|c|}
\hline \multirow{2}{*}{$\begin{array}{c}\text { Dilution } \\
\text { rate } \\
\left(\mathrm{hr}^{-1}\right)\end{array}$} & \multicolumn{3}{|c|}{$\mathrm{Mg}^{2+-}$ limited } & \multicolumn{3}{|c|}{ Glycerol-limited } & \multicolumn{3}{|c|}{$\mathbf{K}^{+}$-limited } & \multicolumn{3}{|c|}{$\mathrm{NH}_{4}{ }^{+}$-limited } \\
\hline & (a) & (b) & $(a / b)$ & (a) & (b) & $(a / b)$ & (a) & (b) & $(a / b)$ & (a) & (b) & $(a / b)$ \\
\hline $0 \cdot 1$ & $\begin{array}{l}0 \cdot 101 \\
0 \cdot 118\end{array}$ & $\begin{array}{c}0 \cdot 101 \\
-\end{array}$ & $\begin{array}{c}1.00 \\
-\end{array}$ & $\begin{array}{c}0.151 \\
-\end{array}$ & $\begin{array}{c}0.130 \\
-\end{array}$ & $\underline{1 \cdot 16}$ & $\begin{array}{l}0 \cdot 148 \\
0 \cdot 150\end{array}$ & $\begin{array}{l}0 \cdot 124 \\
0 \cdot 137\end{array}$ & $\begin{array}{l}1 \cdot 19 \\
1 \cdot 09\end{array}$ & $\begin{array}{l}0 \cdot 192 \\
0 \cdot 220\end{array}$ & $\begin{array}{l}0 \cdot 175 \\
0 \cdot 191\end{array}$ & $\begin{array}{l}1 \cdot 10 \\
1 \cdot 15\end{array}$ \\
\hline $0 \cdot 2$ & $\begin{array}{c}0 \cdot 168 \\
0 \cdot 156 \\
-\end{array}$ & $\begin{array}{c}0 \cdot 166 \\
- \\
-\end{array}$ & $\begin{array}{c}1.01 \\
-\end{array}$ & $\begin{array}{c}0 \cdot 210 \\
- \\
-\end{array}$ & $\begin{array}{c}0 \cdot 179 \\
- \\
-\end{array}$ & $\begin{array}{c}1 \cdot 17 \\
-\end{array}$ & $\begin{array}{l}0 \cdot 178 \\
0 \cdot 182 \\
0 \cdot 183\end{array}$ & $\begin{array}{l}0 \cdot 162 \\
0 \cdot 156 \\
0 \cdot 153\end{array}$ & $\begin{array}{l}1 \cdot 10 \\
1 \cdot 17 \\
1 \cdot 20\end{array}$ & $\begin{array}{c}0 \cdot 227 \\
0 \cdot 264 \\
-\end{array}$ & $\begin{array}{c}0.202 \\
0 \cdot 233 \\
-\end{array}$ & $\begin{array}{c}1 \cdot 12 \\
1 \cdot 13 \\
-\end{array}$ \\
\hline $0 \cdot 4$ & $\begin{array}{c}0 \cdot 214 \\
0 \cdot 220 \\
-\end{array}$ & $\begin{array}{c}0.216 \\
- \\
-\end{array}$ & $\begin{array}{c}0.99 \\
-\end{array}$ & $\begin{array}{c}0.234 \\
0.244 \\
-\end{array}$ & $\begin{array}{c}0 \cdot 198 \\
0 \cdot 208 \\
-\end{array}$ & $\begin{array}{c}1 \cdot 18 \\
1 \cdot 17 \\
-\end{array}$ & $\begin{array}{l}0 \cdot 221 \\
0 \cdot 223 \\
0 \cdot 224\end{array}$ & $\begin{array}{l}0 \cdot 186 \\
0 \cdot 186 \\
0 \cdot 187\end{array}$ & $\begin{array}{l}1 \cdot 19 \\
1 \cdot 19 \\
1 \cdot 19\end{array}$ & $\begin{array}{c}0 \cdot 316 \\
-\end{array}$ & $\begin{array}{c}0.258 \\
- \\
-\end{array}$ & $\begin{array}{c}1.22 \\
-\end{array}$ \\
\hline 0.5 & - & - & - & - & - & - & - & - & - & $0 \cdot 324$ & 0.295 & $1 \cdot 10$ \\
\hline $0 \cdot 6$ & $\begin{array}{c}0.238 \\
0 \cdot 246 \\
-\end{array}$ & $\begin{array}{c}0 \cdot 248 \\
0 \cdot 249 \\
-\end{array}$ & $\begin{array}{c}0.96 \\
0.99 \\
-\end{array}$ & $\begin{array}{c}0 \cdot 274 \\
- \\
-\end{array}$ & $\begin{array}{c}0.231 \\
- \\
-\end{array}$ & $\begin{array}{c}1 \cdot 19 \\
-\end{array}$ & $\begin{array}{l}0 \cdot 256 \\
0 \cdot 240 \\
0 \cdot 266\end{array}$ & $\begin{array}{l}0 \cdot 216 \\
0 \cdot 208 \\
0 \cdot 211\end{array}$ & $\begin{array}{l}1 \cdot 19 \\
1 \cdot 16 \\
1 \cdot 26\end{array}$ & $\begin{array}{c}0.310 \\
-\end{array}$ & $\begin{array}{c}0 \cdot 270 \\
- \\
-\end{array}$ & $\begin{array}{c}1 \cdot 15 \\
-\end{array}$ \\
\hline $0 \cdot 8$ & $\begin{array}{l}0.264 \\
0 \cdot 284\end{array}$ & $\begin{array}{c}0.264 \\
-\end{array}$ & 1.00 & $\begin{array}{l}0.353 \\
0 \cdot 319\end{array}$ & $\begin{array}{l}0.292 \\
0.300\end{array}$ & $\begin{array}{l}1 \cdot 21 \\
1 \cdot 06\end{array}$ & $\begin{array}{c}0.302 \\
-\end{array}$ & - & - & - & - & - \\
\hline
\end{tabular}

Irrespective of the washing procedure, however, the concentration of $\mathrm{Mg}^{2+}$ in the organisms increased with the growth rate. The results also show that $\mathrm{N}$-limited bacteria grown at low dilution rates contained significantly more magnesium than did bacteria growth-limited by other substances at equivalent dilution rates. It seems probable that the higher concentration of $\mathrm{Mg}^{2+}$ in slow growing $\mathrm{N}$-limited bacteria was associated with the presence of a high concentration of bacterial glycogen. Determination of the RNA and $\mathrm{Mg}^{2+}$ contents of bacteria growth-limited by $\mathrm{Mg}^{2+}, \mathrm{K}^{+}$and glycerol showed that the ratio $\mathrm{RNA}: \mathrm{Mg}^{2+}$ varied only slightly with increasing dilution rate in the range $0 \cdot 1-0 \cdot 8 \mathrm{hr}^{-1}$ (Table 2). The RNA content of $\mathrm{Mg}^{2+}$-limited organisms growing at a dilution rate of $0.2 \mathrm{hr}^{-1}$ decreased with 
temperature (Tempest \& Hunter, 1965) and, assuming complete uptake of $\mathrm{Mg}^{2+}$ from the environment, the $\mathrm{Mg}^{2+}$ content increased from $0.135 \%$ (of bacterial dry weight) at $40^{\circ}$ to $0 \cdot 199 \%$ at $25^{\circ}$; the corresponding increase in RNA content was from $9 \cdot 4$ to $14 \cdot 9 \%$.

\section{Table 2. Cellular $\mathrm{RNA}: \mathrm{Mg}^{2+}$ ratios in continuous cultures of Aerobacter aerogenes}

Samples of bacteria separated from chemostat cultures, were washed with $0 \cdot 85 \%(\mathrm{w} / \mathrm{v})$ $\mathrm{NaCl}$ and extracted with ice-cold $0.5 \mathrm{~N}-\mathrm{HClO}_{4}$ and then with $0.5 \mathrm{~N}-\mathrm{HClO}_{4}$ at $80^{\circ}$. The RNA content of the $80^{\circ}$ extract was determined by the orcinol method (see Methods). Similar samples of bacteria were assayed for $\mathrm{Mg}^{2+}$.

$\begin{array}{cccc}\begin{array}{c}\text { Dilution rate } \\ \left(\mathrm{hr}^{-1}\right)\end{array} & \begin{array}{c}\mathrm{Mg}^{2+} \\ \text { organisms }\end{array} & \begin{array}{c}\text { Glycerol- } \\ \text { limited } \\ \text { organisms } \\ \text { g. RNA/g. } \mathbf{M g}^{2+}\end{array} & \begin{array}{c}\mathrm{K}^{+} \text {-limited } \\ \text { organisms }\end{array} \\ 0.1 & \overbrace{\mathbf{7 6}}^{62} & \mathbf{7 0} \\ 0 \cdot 2 & 66 & 52 & 72 \\ 0 \cdot 4 & 71 & 61 & \mathbf{7 9} \\ 0 \cdot 6 & 67 & 60 & 85 \\ 0.8 & 63 & 55 & 82\end{array}$

\section{Effect of adsorbed $\mathrm{Mg}^{2+}$ on the physiology and survival of Aerobacter aerogenes}

It seems probable that the $\mathbf{M g}^{2+}$ which can be removed from glycerol-, $\mathbf{K}^{+-}$or N-limited Aerobacter aerogenes by suspending the organisms in $0.85 \%(w / v) ~ N a C l$ solution is adsorbed to the surface layer of the organisms. The evidence supporting this assumption is that $\mathbf{M g}^{2+}$ taken up by bacteria suspended in $\mathbf{M g S O}_{4}$ solution is quantitatively removed by resuspension of the separated bacteria in $0.85 \%(\mathrm{w} / \mathrm{v})$ $\mathrm{NaCl}$ solution (Strange \& Shon, 1964). The question arises whether this adsorbed $\mathrm{Mg}^{2+}$ serves a functional role in the organisms; various pieces of evidence suggest that it may well do so. For example (1) polysaccharide synthesis by washed suspensions of glycerol-limited $A$. aerogenes in the presence of glycerol was higher with bacteria washed with distilled water than with bacteria washed with saline (Fig. 1). (2) The death rate of water-washed mannitol-limited $A$. aerogenes in saline buffer (pH 6.5) at $40^{\circ}$, with or without mannitol $(40 \mathrm{~mm})$ was lower than that of saline buffer-washed bacteria (Fig. 2); the effect of the washing procedure on substrateaccelerated death (Postgate \& Hunter, 1964) was very marked. (3) As shown previously (Strange \& Shon, 1964), the washing procedure may affect the thermal resistance of bacteria; this was confirmed by heating water-washed and saline phosphate-washed mannitol-limited $A$. aerogenes in saline phosphate $(\mathrm{pH} \mathrm{6.5})$ at $48^{\circ}$ : the death rate of water-washed bacteria was lower than that of phosphatewashed bacteria (Fig. 3). To confirm that the lower heat resistance of saline phosphate-washed bacteria was due to loss of adsorbed $\mathrm{Mg}^{2+}$ during washing, bacteria were washed successively with saline phosphate (to desorb $\mathrm{Mg}^{2+}$ ), $\mathrm{mM}_{\mathrm{M}} \mathrm{MgSO}_{4}$ and finally with distilled water (to remove excess $\mathrm{MgSO}_{4}$ ). The survival characteristics of these bacteria were similar to those of water-washed bacteria (Fig. 3). Also, the presence of $\mathrm{mM}^{-\mathrm{MgSO}_{4}}$ in saline phosphate during heating of saline phosphatewashed bacteria decreased the death rate (Fig. 3). (4) Sudden chilling caused loss of viability of suspensions of exponential phase $A$. aerogenes (Strange \& Dark, 1962; Strange \& Postgate, 1964) and it was found that the washing procedure affected 
the susceptibility of the organisms to cold shock. Water-washed organisms were less susceptible to chilling in saline buffer ( $\mathrm{pH} \mathrm{6.5)} \mathrm{than} \mathrm{organisms} \mathrm{washed} \mathrm{with}$ solutions of $\mathrm{NaCl}$ or sodium phosphate buffer (Fig. 4).

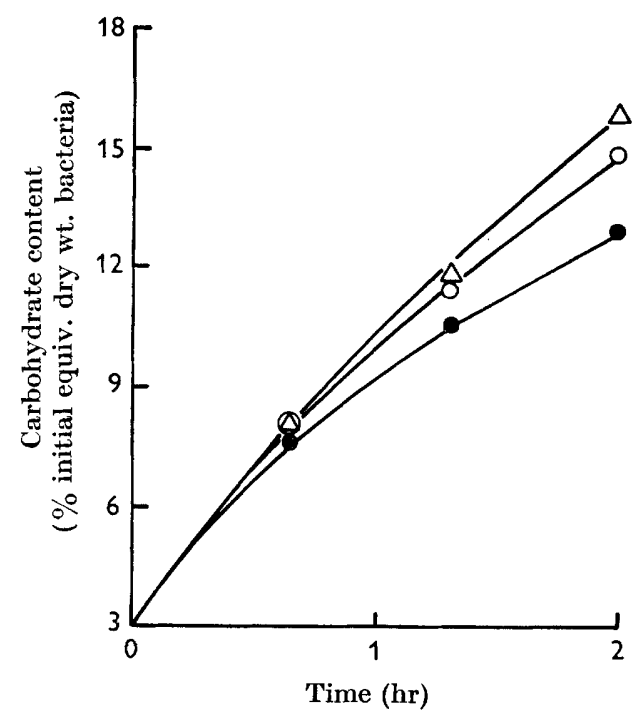

Fig. 1

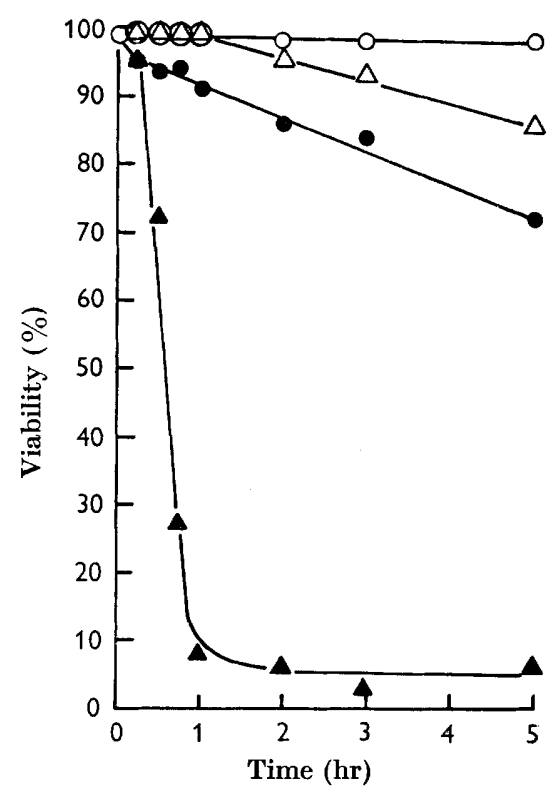

Fig. 2

Fig. 1. Carbohydrate synthesis in washed suspensions of glycerol-limited Aerobacter aerogenes. Organisms from a glycerol-limited culture $\left(37^{\circ}\right.$, dilution rate $\left.=0 \cdot 4 \mathrm{hr}^{-1}\right)$ were separated from the culture by centrifugation $(3000 \mathrm{~g}, 5 \mathrm{~min}$.) and washed either twice in water $(O)$, twice in $0 \cdot 85 \%(\mathrm{w} / \mathrm{v}) \mathrm{NaCl}(\mathrm{O})$ or once each, successively, in saline, $0 \cdot 01 \mathrm{M}-\mathrm{MgCl}_{2}$, water $(\triangle)$. Washed organisms were resuspended at a concentration equiv. $1 \mathrm{mg}$. dry wt. bacteria $/ \mathrm{ml}$. in $0.067 \mathrm{M}$-phosphate $(\mathrm{pH} 6.5)+0.05 \mathrm{M}$ glycerol and incubated at $37^{\circ}$, with aeration. Samples were analysed for carbohydrate as indicated in Methods.

Fig. 2. Survival of water-washed and saline phosphate-washed Aerobacter aerogenes at $40^{\circ}$ in aerated saline phosphate $(\mathrm{pH} 6 \cdot 5)$, with or without mannitol. Continuously grown mannitol-limited bacteria (dilution rate, $0.4 \mathrm{hr}^{-1}$ ) were washed twice with distilled water or saline phosphate and resuspended (about $4 \times 10^{8}$ bacteria/ml.) in aerated saline phosphate with and without mannitol $(40 \mathrm{~mm})$. Viabilities (slide culture) of suspensions of water-washed $(O, \ominus)$ and saline phosphate-washed $(\triangle, \Delta)$ bacteria. Open symbols, buffer; closed symbols, buffer plus mannitol.

\section{DISCUSSION}

The present results confirm previous reports that bacterial RNA (Herbert, 1961, Neidhardt, 1963) and magnesium (Tempest et al. 1965) increase with the growth rate of bacteria. The fact that the ratio of RNA:magnesium in Aerobacter aerogenes varied only slightly with dilution rate suggests that a large proportion of the magnesium was associated with the RNA. This view is strengthened by the finding (Tempest \& Hunter, 1965) that when the RNA content of magnesium-limited bacteria growing at a fixed dilution rate was varied by altering the incubation temperature, a corresponding change in the magnesium content of the bacteria apparently occurred. Most of the cellular RNA is present in ribosomes which are 
known to have magnesium as an integral part of their structure (Edelman, Ts'o \& Vinograd, 1960; Rogers, 1964). However, proof that the magnesium requirement of bacteria increases with the growth rate mainly for the purpose of stabilizing an increasing number of ribosomes would require more precise data than those obtained here about the distribution of $\mathrm{Mg}^{2+}$ in bacteria. The present results show that in bacteria separated from environments containing an excess of magnesium, a proportion of their magnesium is loosely bound and removed by washing with saline, whereas magnesium-limited bacteria had no loosely bound magnesium associated

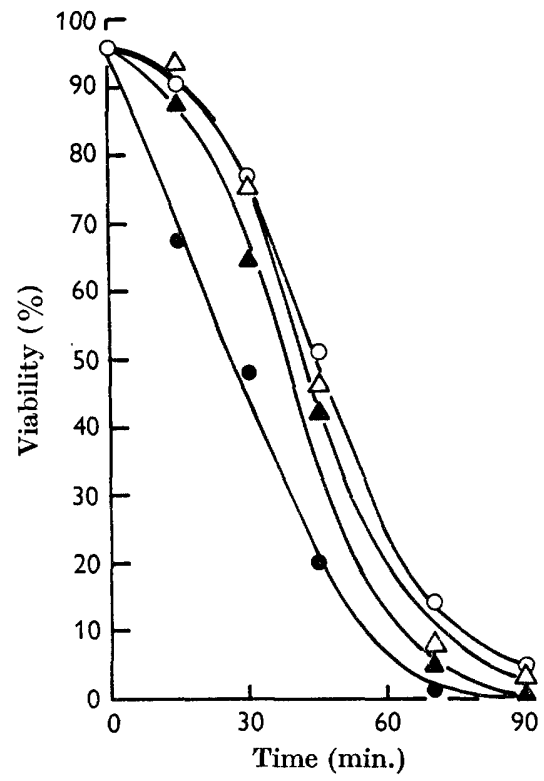

Fig. 3

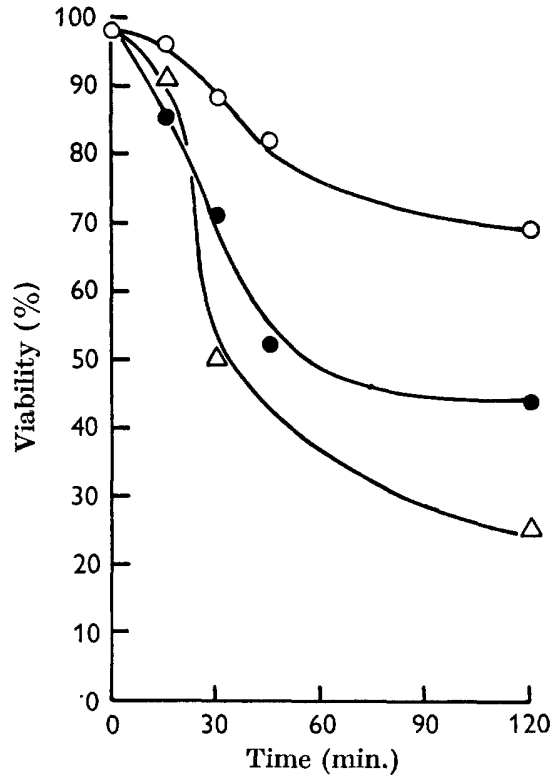

Fig. 4

Fig. 3. Survival of water-washed and saline phosphate-washed Aerobacter aerogenes at $48^{\circ}$ in aerated saline phosphate (pH 6.5). Continuously grown mannitol-limited bacteria (dilution rate, $0.25 \mathrm{hr}^{-1}$ ) were washed: $(a)$ three times with distilled water $(O) ;(b)$ once with saline phosphate and twice with water $(\boldsymbol{O}, \mathbf{\Delta})$; $(c)$ successively with saline phosphate, $1 \mathrm{~mm}-\mathrm{MgSO}_{4}$ and water $(\Delta)$. The washed organisms were resuspended in water and samples were diluted 1/100 (final bacterial concentration about $3 \times 10^{8} / \mathrm{ml}$.) in aerated saline phosphate, with (A) and without $1 \mathrm{~mm}-\mathrm{MgSO}_{4}$, at $48^{\circ}$. Viabilities were determined by slide culture.

Fig. 4. Effect of washing procedure on the susceptibility of exponential phase Aerobacter aerogenes to chilling at $0^{\circ}$. Bacteria growing exponentially in shaken flasks of defined medium at $37^{\circ}$ were separated and washed with distilled water $(0), 0 \cdot 15 \mathrm{M}-\mathrm{NaCl}(\odot)$ or $0.075 \mathrm{M}$-sodium phosphate buffer $(\mathrm{pH} 6.5)(\triangle)$. Samples of the washed organisms suspended in the washing liquid were diluted $1 / 40$ (final concentration about $3 \times 10^{7}$ bacteria $/ \mathrm{ml}$.) in saline phosphate $\left(\mathrm{pH} \mathrm{6.5)}\right.$ at $0^{\circ}$. Viabilities were determined by slide culture.

with them. While adsorbed magnesium is evidently not necessary for growth, it did affect both the ability of the organisms to synthesize polysaccharide in the presence of glycerol and their resistance to various stresses. Therefore this adsorbed magnesium may have an important functional role in bacteria and this should be considered when preparing washed bacterial suspensions for studies of metabolic activity or survival. 
We wish to thank our colleague Dr J. W. Dicks for some magnesium determinations and Mr T. H. Dunham for his skilled technical assistance.

\section{REFERENCES}

Edelman, I. S., Ts'o, P. O. P. \& Vinograd, J. (1960). The binding of magnesium to microsomal nucleoprotein and ribonucleic acid. Biochim. biophys. Acta, 43, 393.

GardNer, R. J. (1946). Colorimetric determination of magnesium in plasma or serum by means of Titan Yellow. Biochem. J. 40, 828.

Herbert, D. (1961). The chemical composition of microorganisms as a function of their environment. In Microbiol Reaction to Environment. Symp. Soc. gen. Microbiol. 11, 391.

Herbert, D., Phipps, P. J. \& Tempest, D. W. (1965). The chemostat: design and instrumentation. Lab. Practice, 14, 1150.

NeIDHardt, F. C. (1963). Effect of environment, on the composition of bacterial cells. Annu. Rev. Microbiol. 17, 61.

Postgate, J. R. \& Hunter, J. R. (1962). The survival of starved bacteria. J. gen. Microbiol. 29, 233.

Postgate, J. R. \& Hunter, J. R. (1963). Acceleration of bacterial death by growth substrates. Nature, Lond. 198, 273.

Postgate, J. R. \& Hunter, J. R. (1964). Accelerated death of Aerobacter aerogenes starved in the presence of growth-limiting substrates. J. gen. Microbiol. 34, 459.

Postgate, J. R., Crumpton, J. E. \& Hunter, J. R. (1961). The determination of bacterial viabilities by slide culture. J. gen. Microbiol. $24,15$.

Rogers, A. (1964). The exchange properties of magnesium in Escherichia coli ribosomes. Biochem. J. 90, 548.

Strange, R. E. \& Dark, F. A. (1962). Effect of chilling on Aerobacter aerogenes in aqueous suspension. J. gen. Microbiol. $29,719$.

Strange, R. E. \& Dark, F. A. (1965). 'Substrate-accelerated death' of Aerobacter aerogenes. J. gen. Microbiol. 39, 215.

Strange, R. E. \& Postgate, J. R. (1964). Penetration of substances into cold-shocked bacteria. J. gen. Microbiol. 36, 393.

Strange, R. E. \& Shon, M. (1964). Effects of thermal stress on viability and ribonucleic acid of Aerobacter aerogenes in aqueous suspension. J. gen. Microbiol. 34, 99.

Tempest, D. W. \& HunTer, J. R. (1965). The influence of temperature and pH value on the macromolecular composition of magnesium-limited and glycerol-limited Aerobacter aerogenes growing in a chemostat. J. gen. Microbiol. 41, 267.

Tempest, D. W., Hunter, J. R. \& Sykes, J. (1965). Magnesium-limited growth of Aerobacter aerogenes in a chemostat. J. gen. Microbiol. 39, 355. 